\title{
EFFECTS STUDY OF NIGELLA SATIVA, ITS OIL AND THEIR COMBINATION WITH VITAMIN E ON OXIDATIVE STRESS IN RATS
}

\author{
Amr A. Rezq \\ Department of Nutrition and Food Sciences, \\ Faculty of Home Economics, Helwan University, Cairo, Egypt
}

Received 2014-01-26; Revised 2014-02-03; Accepted 2014-04-23

\begin{abstract}
Antioxidants or free radical scavengers are very important in protecting the living cells against any damage induced by free radicals. The effects of Nigella Sativa Extract (NSE), Nigella Sativa Oil (NSO) and Vitamin E (Vit. E) and the combination of NSE or NSO with Vit. E on potassium bromate $\left(\mathrm{KBrO}_{3}\right)$-induced oxidative stress in male rats were investigated. Forty nine Sprague Dawley male rats were weighingv $185 \pm 5$ $\mathrm{g}$ and 10-12 weeks old were used to achieve the present study. According to the results, oral administration of NSE or NSO alone and in combination with vitamin E exhibited weight gain and feed efficiency ratio and lowered the elevated serum levels of total cholesterol, triglycerides, AST, ALT, urea nitrogen, uric acid and creatinine. Further, they lowered malondialdehyde and increased the reduction in glutathione content and activities of antioxidant enzymes (GPx, SOD and CAT) in liver tissues. Collectively, these results indicate that dietary intake of NSE or NSO alone and in combination with Vitamin E could be a potential therapeutic in the treatment of related diseases with oxidative stress.
\end{abstract}

Keywords: Nigella Sativa, Vitamin E, Oxidative Stress, Antioxidants, Hepato and Renal Functions, Rats

\section{INTRODUCTION}

Oxidative stress is a state in which oxidation processes exceeds the antioxidant systems in the body. Oxidative stress arises from an imbalance between the production of Reactive Oxygen Species (ROS) and the body's antioxidant defenses against them, which induces cellular damage. The antioxidant defenses enable the body system to remove ROS, restore the prevailing reducing environment and repair the tissue damage (Halliwell and Gutteridge, 1999). Free radicals such as Nitric Oxide (NO) and superoxide ions are produced as second messengers, particularly by immune cells. Superoxide reacts rapidly with nitric oxide by nitric oxide synthase to produce peroxynitrite, whereas Hydrogen Peroxide $\left(\mathrm{H}_{2} \mathrm{O}_{2}\right)$ slowly decomposes to the highly reactive hydroxyl radical. Both peroxynitrite and hydroxyl radicals are highly reactive oxidizing agents, capable of damaging proteins, lipids and DNA (Beckman and Koppenol, 1996). Oxidative stress plays an important role in the etiology and pathogenesis of many chronic diseases such as atherosclerosis, hypertension, diabetes mellitus and cancers (Reuter et al., 2010; Krajcovicova-Kudlackova et al., 2012).

Potassium Bromate $\left(\mathrm{KBrO}_{3}\right)$ is widely used as a food additive in the bread making processes and found in drinking water samples as a byproduct of ozone disinfection. $\mathrm{KBrO}_{3}$ causes renal cell cancer and act as a tumor promoter in carcinogen-initiated animals. Renal cell tumors have been reported after exposure to $\mathrm{KBrO}_{3}$ due to its oxidative stress in rats (Kurokawa et al., 1990).

Dietary intake of antioxidants can inhibit or delay the oxidation of susceptible cellular substrates so prevent oxidative stress (Rice-Evans et al., 1996). Therefore, it is important to enrich our diet with antioxidants to protect against oxidative stress that represents as a risk factor for many chronic diseases. Moreover, antioxidants play an important role in food quality preservation due to their ability to prevent oxidative deterioration of lipids (Erukainure et al., 2012). 
Nigella sativa (N. sativa, also known black seed, Family Ranunculaceae) seeds are used as nutritional flavoring agent and traditionally as natural remedy for many chronic diseases. Previous studies reported that $\mathrm{N}$. sativa seeds possess antitumor (Worthen et al., 1998); immunostimulant (Haq et al., 1999); antioxidant (Burits and Bucar, 2000) and antidiabetic (Meral et al., 2001) properties. Most of N. sativa properties have been attributed mainly to the quinone constituents of which thymoquinone, the main bioactive ingredient of the oil isolated from N. sativa seeds. Thymoquinone was reported to possess good antioxidant (Houghton et al., 1995), anti-inflammatory (Ragheb et al., 2009) and anticancer (Randhawa and Alghamdi, 2011) effects.

Vitamin E (alpha tocopherol) is a fat soluble vitamin which regulates oxidation processes in the body as it acts as a powerful antioxidant. Previous studies showed that intake of vitamin E could prevent the damaging effects of Reactive Oxygen Species (ROS) and free radicals (Shalaby et al., 2004). Moreover, supplementation of diet with vitamin E can protect sperm DNA from oxidative stress of free radicals (Jedlinska et al., 2006) in rats and increase the activity of enzymes involved in the removal of ROS generated by cell metabolism (Caetano et al., 2013). Therefore, the present study was conducted in an effort to investigate the effects of Nigella sativa extract and its oil alone and in combinations with vitamin $\mathrm{E}$ on the oxidative stress induced by potassium bromate in male rats.

\section{MATERIALS AND METHODS}

\subsection{Materials}

\subsubsection{Nigella Sativa and its Oil}

Dried seeds of Nigella sativa (Family Ranunculaceae) and its oil were purchased from a local market of Agricultural Herbs, Spices and Medicinal plants, Cairo, Egypt. The seeds of N. sativa were authenticated in Botany Department, Faculty of Agriculture, Cairo University. The dried seeds of $\mathrm{N}$. sativa were grinded using a coffee grinder into a fine powder before extraction.

\subsection{Rats and Basal Diet}

Forty nine mature male rats of Sprague Dawley strain weighing $185 \pm 5 \mathrm{~g}$ body weight and 10-12 weeks old were obtained from the Laboratory Animals Farm, Helwan, Egypt. Basal diet constituents (Casein, cellulose, vitamin mixture, mineral mixture and choline chloride) were purchased from El-Gomhorya Company for Pharmaceutical and Chemical, Cairo, Egypt.

\subsection{Chemicals}

Potassium Bromate $\left(\mathrm{KBrO}_{3}\right)$ in the form of white powder (soluble in boiling water) was purchased from El-Gomhoryia Company, Cairo Egypt. Vitamin E was obtained from Pharco Company for Pharmaceuticals, Alexandria, Egypt. It was dispensed in the form of soft gelatin capsules each containing $1000 \mathrm{mg}$-alpha tocopherol acetate. Biochemical kits for the determination of liver enzymes (AST, ALT), total cholesterol, triglycerides urea nitrogen, uric acid and creatinine, were purchased from Alkan Company for Chemicals and Biodiagnostics, Dokki, Cairo, Egypt.

\subsection{Methods}

\subsubsection{Preparation of Nigella Sativa Seeds Extract (NSE)}

Nigella sativa extract was prepared by soaking $200 \mathrm{~g}$ of the grinded dry seeds in 1 liter $90 \%$ ethyl alcohol and kept in a refrigerator with daily shaking for 5 days. The ethanol was then evaporated using a rotatory evaporator apparatus (manufactured in West Germany) attached with a vacuum pump. Twenty grams of the obtained semisolid extract were suspended in distilled water with $2 \mathrm{~mL}$ of Tween 80 (suspending agent) and $80 \mathrm{~mL}$ of distilled water were gradually added to obtain $20 \%$ liquid extract.

\subsection{Preparation of Basal Diet}

The basal diet was prepared using AIN-93 according to Reeves et al. (1993). It consists of $20 \%$ protein (casein), $10 \%$ sucrose, $4.7 \%$ corn oil, $2 \%$ choline chloride, $1 \%$ vitamin mixture, $3.5 \%$ salt mixture and $5 \%$ fibers (cellulose). The remainder was corn starch up to $100 \%$.

\subsection{Experimental Design and Grouping of Rats}

All animals were housed at a controlled room temperature of $23 \pm 1^{\circ} \mathrm{C}, 55 \%$ humidity and under a $12 \mathrm{~h}$ light/12-h dark schedule. The animals were fed on basal diet and water was provided ad libitum for one week before starting of the experiment for acclimatization. After one week adaptation period, the rats were randomly distributed into 7 equal groups, of 7 rats each. Group I was fed on basal diet and kept as a negative control group (normal rats). The other 6 groups were injected by a single intraperitoneal dose of potassium bromate at dose of $125 \mathrm{mg} \mathrm{kg}$-1 body weight for induction of oxidative stress according to the methods described by Khan and Sultana (2004). Group II was left as a positive control group and groups III, IV, V, VI and VII were given orally Nigella Sativa Extract (NSE) at $200 \mathrm{mg} \mathrm{kg}^{-1}$, Oil (NSO) at $1 \mathrm{~mL} \mathrm{~kg}^{-1}$, vitamin E (Vit. 
E) at $100 \mathrm{mg} \mathrm{kg}^{-1}, \mathrm{NSE}+\mathrm{Vit} \mathrm{E}$ and $\mathrm{NSO}+\mathrm{Vit} \mathrm{E}$, respectively for 8 weeks.

The food intake was calculated daily and the body weight gain was recorded weekly. Feed Efficiency Ratio (FER) was calculated as FER = weight gain $(\mathrm{g}) /$ feed intake (g). At the end of experimental period ( 8 weeks), the rats were anesthetized using ether anesthetic and blood samples were collected into clean centrifuge tubes to obtain the serum which used for biochemical analyses. Livers were immediately removed, rinsed with normal saline, then blotted on filter paper and stored at $-70^{\circ} \mathrm{C}$ pending for the preparation of liver homogenate for biochemical assays.

\subsection{Biochemical Analysis}

Activities of serum liver enzymes aspartate and alanine aminotransferases (AST and ALT) were chemically determined according to Bergmeyer et al. (1978). Serum concentrations of total cholesterol and triglycerides were chemically determined as described by (Ratliff and Hall, 1973. Jacob and Van-Denmark, 1960), respectively. Blood Urea Nitrogen levels (BUN) was determined using BioMerieux kits according to Patton and Crouch (1977). Serum uric acid was determined using the enzymatic colorimetric method as described by Fossati et al. (1980). Serum creatinine concentrations were colorimetrically determined by the Jaffe reaction (Husdan and Rapoport, 1968).

\subsection{Lipid Peroxidation and Antioxidant Enzymes in Liver Tissues}

One gram of the frozen liver tissues was collected, washed in ice-cold $0.9 \% \mathrm{NaCl}$ and homogenized in ice-cold $1.15 \%$ solution of potassium chloride and $50 \mathrm{mmol}$ potassium phosphate buffer solutions ( $\mathrm{pH} 7.4$ ) to yield $10 \%$ homogenate $(\mathrm{W} / \mathrm{V})$. Homogenization was performed using ultrasonic homogenizer (Sonicator, model 4710, ColeParmer Instrument Company, USA). The homogenate was then centrifuged at $4000 \mathrm{rpm}$ for $15 \mathrm{~min}$ at $4^{\circ} \mathrm{C}$ and the supernatant was collected for further use.

Lipid Peroxidation (LPO) was determined by quantifying malondialdehyde (MDA) that formed in terms of Thiobarbituric Acid Reactive Substances (TBARS). Liver homogenate was used for determination of tissue lipid peroxide (MDA), enzymatic (GPx, SOD and CAT) and non enzymatic (GSH) antioxidants. Malondialdehyde was determined according to Ohkawa et al. (1979). The reduced glutathione (GSH) content in liver homogenate was determined colorimetrically by the method modified by Bulaj et al. (1998). Activities of Glutathione Peroxidase (GPx), Superoxide Dismutase (SOD) and Catalase (CAT) antioxidant enzymes were determined chemically according to (Paglia and Valentaine, 1979; Spitz and Oberley, 1989; Sinha, 1972), respectively.

\subsection{Statistical Analysis}

Data are expressed as mean \pm standard division $($ Mean \pm SD). Differences between the groups were tested for significance using one-way Analysis Of Variance (ANOVA) followed by Duncan's multiple range test. Statistical analyses were performed using the SPSS software (Statistical Package for the Social Sciences, version 16.00, Chicago, USA).

\section{RESULTS}

Intraperitoneal injection of potassium bromate in a single dose (125 $\mathrm{mg} \mathrm{kg}^{-1}$ b.wt.) to rats caused significant $(\mathrm{p}<0.05)$ decreases in Feed Intake (FI), body weight gain (\%) and Feed Efficiency Ratio (FER) when compared to the negative control group. In rats with oxidative stress, the oral administration of NSE or NSE alone and in combination with vitamin $\mathrm{E}$ for 8 weeks caused significant $(\mathrm{p}<0.05)$ increases in feed intake, bodyweight gain and feed efficiency ratio when compared with the positive control group as shown in Table $\mathbf{1}$.

As shown in Table 2, the rats received potassium bromate had significant $(\mathrm{p}<0.05)$ increases in serum levels of liver enzymes (AST and ALT), Total Cholesterol (TC) and Triglycerides (TG) when compared to the negative control group. Oral administration of NSE or NSE alone and in combination with vitamin E caused significant $(\mathrm{p}<0.05)$ decreases in the elevated serum levels of AST, ALT, TC and TG when compared with the positive control group.

Tabulated data, showed that positive rats (untreated group) had significant $(\mathrm{p}<0.05)$ increased in serum levels of Blood Urea Nitrogen (BUN), Uric Acid (UA) and Creatinine ( $\mathrm{Cr}$ ), compared with the negative control group (normal rats). In contrast, oral administration of NSE or NSE alone and in combination with vitamin $\mathrm{E}$ to rats with oxidative stress for 8 weeks significantly $(\mathrm{p}<0.05)$ decreased serum levels of BUN, UA and $\mathrm{Cr}$ when compared with the positive control group as shown in Table 3.

In liver tissues of rats with oxidative stress, results recorded that there was a significant $(\mathrm{p}<0.05)$ decrease in hepatic level of reduced Glutathione (GSH) and an increase in lipid peroxide Malondialdehyde (MDA) when compared to the normal group. Rats with oxidative stress when orally given NSE or NSE alone and in combination with vitamin $E$ significantly $(p<0.05)$ increased GSH and decreased MDA in hepatic tissue as compared to the control positive group (Table 4). 
Amr A. Rezq / American Journal of Applied Sciences 11 (7): 1079-1086, 2014

Table 1. Feed intake, final body weight, body weight gain and feed efficiency in rats

\begin{tabular}{|c|c|c|c|c|}
\hline Groups & FI (g) & FBW $(\mathrm{g})$ & $\mathrm{BWG}(\%)$ & FER \\
\hline Group 1 & & & & \\
\hline $\begin{array}{l}\text { Negative control } \\
\text { Group } 2\end{array}$ & $16.85 \pm 2.3^{\mathrm{a}}$ & $233.7 \pm 5.3^{\mathrm{a}}$ & $18.95 \pm 1.3^{\mathrm{a}}$ & $0.69 \pm 0.04^{\mathrm{a}}$ \\
\hline $\begin{array}{l}\text { Positive control } \\
\text { Group } 3\end{array}$ & $12.46 \pm 1.1^{\mathrm{d}}$ & $199.5 \pm 6.3^{\mathrm{d}}$ & $15.86 \pm 1.6^{\mathrm{c}}$ & $0.29 \pm 0.01^{\mathrm{c}}$ \\
\hline $\begin{array}{l}\text { NSE }\left(200 \mathrm{mg} \mathrm{kg}^{-1}\right) \\
\text { Group } 4\end{array}$ & $13.91 \pm 2.2^{\mathrm{b}}$ & $206.2 \pm 7.2^{b}$ & $16.26 \pm 1.1^{\mathrm{b}}$ & $0.35 \pm 0.03^{b}$ \\
\hline $\begin{array}{l}\text { NSO }\left(1 \mathrm{~mL} \mathrm{~kg}^{-1}\right) \\
\text { Group } 5\end{array}$ & $14.52 \pm 2.3^{b}$ & $211.5 \pm 6.3^{b}$ & $16.72 \pm 1.4^{\mathrm{b}}$ & $0.39 \pm 0.01^{\mathrm{b}}$ \\
\hline $\begin{array}{l}\text { Vit E }\left(100 \mathrm{mg} \mathrm{kg}^{-1}\right) \\
\text { Group } 6\end{array}$ & $14.75 \pm 3.6^{\mathrm{b}}$ & $218.3 \pm 5.3^{b}$ & $16.95 \pm 1.8^{\mathrm{b}}$ & $0.40 \pm 0.03^{\mathrm{b}}$ \\
\hline $\begin{array}{l}\text { NSE + Vit E } \\
\text { Group } 7\end{array}$ & $15.42 \pm 2.4^{\mathrm{c}}$ & $228.3 \pm 6.3^{c}$ & $18.16 \pm 1.5^{\mathrm{c}}$ & $0.52 \pm 0.04^{c}$ \\
\hline $\mathrm{NSO}+\mathrm{Vit} \mathrm{E}$ & $15.82 \pm 2.1^{\mathrm{c}}$ & $231.2 \pm 5.2^{\mathrm{c}}$ & $18.26 \pm 1.7^{\mathrm{b}}$ & $0.59 \pm 0.04^{\mathrm{c}}$ \\
\hline
\end{tabular}

Mean \pm SD values in each raw with different superscripts ( $a, b, c, d)$ are significant when compared to the control groups at $p<0.05 . n$ $=7$ rats/group

Table 2. Serum concentrations of AST, ALT, TC and TG in rats

\begin{tabular}{|c|c|c|c|c|}
\hline Groups & $\operatorname{AST}(\mathrm{U} / \mathrm{L})$ & $\operatorname{ALT}(\mathrm{U} / \mathrm{L})$ & $\mathrm{TC}(\mathrm{mg} / \mathrm{dL})$ & $\mathrm{TG}(\mathrm{mg} / \mathrm{dL})$ \\
\hline \multicolumn{5}{|l|}{ Group I } \\
\hline Negative control & $64.15 \pm 4.3^{\mathrm{d}}$ & $33.7 \pm 2.3^{\mathrm{d}}$ & $94.50 \pm 3.4^{\mathrm{d}}$ & $53.4 \pm 2.4^{\mathrm{d}}$ \\
\hline \multicolumn{5}{|l|}{ Group II } \\
\hline Positive control & $97.54 \pm 2.1^{\mathrm{a}}$ & $45.5 \pm 2.1^{\mathrm{a}}$ & $115.86 \pm 5.6^{\mathrm{a}}$ & $72.5 \pm 3.1^{\mathrm{a}}$ \\
\hline \multicolumn{5}{|l|}{ Group III } \\
\hline NSE $\left(200 \mathrm{mg} \mathrm{kg}^{-1}\right)$ & $85.61 \pm 3.2^{\mathrm{b}}$ & $40.2 \pm 1.2^{\mathrm{b}}$ & $111.26 \pm 6.1^{\mathrm{b}}$ & $66.2 \pm 2.3^{b}$ \\
\hline \multicolumn{5}{|l|}{ Group IV } \\
\hline $\operatorname{NSO}\left(1 \mathrm{ml} \mathrm{kg}^{-1}\right)$ & $80.42 \pm 3.3^{\mathrm{b}}$ & $39.5 \pm 2.3^{\mathrm{b}}$ & $110.72 \pm 5.4^{\mathrm{b}}$ & $60.6 \pm 4.1^{\mathrm{b}}$ \\
\hline \multicolumn{5}{|l|}{ Group V } \\
\hline Vit E $\left(100 \mathrm{mg} \mathrm{kg}^{-1}\right)$ & $78.25 \pm 2.6^{\mathrm{b}}$ & $38.3 \pm 1.6^{\mathrm{b}}$ & $105.95 \pm 4.8^{\mathrm{b}}$ & $59.0 \pm 3.3^{\mathrm{b}}$ \\
\hline \multicolumn{5}{|l|}{ Group VI } \\
\hline $\mathrm{NSE}+\mathrm{Vit} \mathrm{E}$ & $72.40 \pm 3.4^{\mathrm{c}}$ & $36.3 \pm 1.4^{\mathrm{c}}$ & $102.16 \pm 3.5^{\mathrm{c}}$ & $56.0 \pm 2.4^{\mathrm{c}}$ \\
\hline \multicolumn{5}{|l|}{ Group VII } \\
\hline $\mathrm{NSO}+\mathrm{Vit} \mathrm{E}$ & $72.50 \pm 1.1^{\mathrm{c}}$ & $34.2 \pm 1.7^{\mathrm{c}}$ & $98.26 \pm 4.7^{\mathrm{c}}$ & $55.6 \pm 2.8^{\mathrm{c}}$ \\
\hline
\end{tabular}

Table 3. Concentrations of BUN, UA and Cr in rats

\begin{tabular}{|c|c|c|c|}
\hline Groups & BUN (mg/dL) & $\mathrm{UA}(\mathrm{mg} / \mathrm{dL})$ & $\mathrm{Cr}(\mathrm{mg} / \mathrm{dL})$ \\
\hline \multicolumn{4}{|l|}{ Group I } \\
\hline Negative control & $15.5 \pm 0.4^{\mathrm{d}}$ & $2.26 \pm 0.03^{\mathrm{d}}$ & $1.22 \pm 0.03^{\mathrm{d}}$ \\
\hline \multicolumn{4}{|l|}{ Group II } \\
\hline Positive control & $25.4 \pm 0.3^{\mathrm{a}}$ & $3.65 \pm 0.01^{\mathrm{a}}$ & $2.11 \pm 0.06^{\mathrm{a}}$ \\
\hline \multicolumn{4}{|l|}{ Group III } \\
\hline NSE $\left(200 \mathrm{mg} \mathrm{kg}^{-1}\right)$ & $19.9 \pm 0.2^{b}$ & $3.24 \pm 0.02^{\mathrm{b}}$ & $1.95 \pm 0.01^{\mathrm{b}}$ \\
\hline \multicolumn{4}{|l|}{ Group IV } \\
\hline $\operatorname{NSO}\left(1 \mathrm{ml} \mathrm{kg}^{-1}\right)$ & $18.5 \pm 0.3^{b}$ & $2.95 \pm 0.03^{\mathrm{b}}$ & $1.77 \pm 0.04^{\mathrm{b}}$ \\
\hline \multicolumn{4}{|l|}{ Group V } \\
\hline Vit E (100 mg kg-1) & $17.7 \pm 0.6^{\mathrm{b}}$ & $2.86 \pm 0.01^{\mathrm{b}}$ & $1.66 \pm 0.04^{b}$ \\
\hline \multicolumn{4}{|l|}{ Group VI } \\
\hline $\mathrm{NSE}+\mathrm{Vit} \mathrm{E}$ & $16.9 \pm 0.4^{\mathrm{c}}$ & $2.35 \pm 0.01^{\mathrm{c}}$ & $1.44 \pm 0.05^{\mathrm{c}}$ \\
\hline \multicolumn{4}{|l|}{ Group VII } \\
\hline $\mathrm{NSO}+\mathrm{Vit} \mathrm{E}$ & $16.2 \pm 0.1^{\mathrm{c}}$ & $2.30 \pm 0.02^{\mathrm{c}}$ & $1.30 \pm 1.07^{\mathrm{c}}$ \\
\hline
\end{tabular}

Mean \pm SD values in each raw with different superscripts (a, b, c, d) are significant when compared to the control groups at $\mathrm{p}<0.05 . \mathrm{n}=7$ rats/group 
Table 4. Hepatic tissues contents of GSH and MDA in rats

\begin{tabular}{lll} 
Groups & $\begin{array}{l}\text { GSH } \\
(\mathrm{nmol} / \mathrm{min} / \mathrm{mg} \text { protein })\end{array}$ & $\begin{array}{l}\text { MDA } \\
(\mathrm{nmol} / \mathrm{min} / \mathrm{mg} \mathrm{protein})\end{array}$ \\
\hline $\begin{array}{l}\text { Group I } \\
\text { Negative control }\end{array}$ & $23.5 \pm 0.2^{\mathrm{a}}$ & $2.26 \pm 0.03^{\mathrm{d}}$ \\
$\begin{array}{l}\text { Group II } \\
\text { Positive control }\end{array}$ & $14.6 \pm 0.1^{\mathrm{d}}$ & $3.65 \pm 0.01^{\mathrm{a}}$ \\
Group II & $17.2 \pm 0.3^{\mathrm{b}}$ & $3.24 \pm 0.02^{\mathrm{b}}$ \\
NSE (200 mg kg & \\
Group IV & $18.5 \pm 0.2^{\mathrm{b}}$ & $2.95 \pm 0.03^{\mathrm{b}}$ \\
NSO (1 ml kg & \\
Group V & $19.7 \pm 0.3^{\mathrm{b}}$ & $2.86 \pm 0.01^{\mathrm{b}}$ \\
Vit E (100 mg kg & \\
Group VI & $21.9 \pm 0.2^{\mathrm{c}}$ & $2.45 \pm 0.01^{\mathrm{c}}$ \\
NSE + Vit E & $22.2 \pm 0.1^{\mathrm{c}}$ & $2.38 \pm 0.02^{\mathrm{c}}$ \\
Group VII & NSO + Vit E &
\end{tabular}

Mean \pm SD values in each raw with different superscripts $(a, b, c, d)$ are significant when compared to the control groups at $\mathrm{p}<0.05 . \mathrm{n}=7$ rats/group

Table 5. Hepatic levels of antioxidant enzymes (GPx, SOD and CAT) in rats

\begin{tabular}{|c|c|c|c|}
\hline Groups & $\begin{array}{l}\text { GPx } \\
\text { (nmol/min/mg protein) }\end{array}$ & $\begin{array}{l}\text { SOD } \\
\text { (U/mg protein) }\end{array}$ & $\begin{array}{l}\text { CAT } \\
\text { (nmol/min/mg protein) }\end{array}$ \\
\hline Group I & & & \\
\hline Negative control & $0.80 \pm 0.04^{\mathrm{a}}$ & $56.62 \pm 2.63^{\mathrm{a}}$ & $0.187 \pm 0.03^{\mathrm{a}}$ \\
\hline Group II & & & \\
\hline $\begin{array}{l}\text { Positive control } \\
\text { Group III }\end{array}$ & $0.22 \pm 0.03^{\mathrm{d}}$ & $32.55 \pm 2.21^{\mathrm{d}}$ & $0.127 \pm 0.02^{\mathrm{d}}$ \\
\hline $\begin{array}{l}\text { NSE }\left(200 \mathrm{mg} \mathrm{kg}^{-1}\right) \\
\text { Group IV }\end{array}$ & $0.39 \pm 0.01^{\mathrm{b}}$ & $36.24 \pm 2.42^{\mathrm{b}}$ & $0.133 \pm 0.01^{\mathrm{b}}$ \\
\hline $\begin{array}{l}\text { NSO }\left(1 \mathrm{~mL} \mathrm{~kg}^{-1}\right) \\
\text { Group V }\end{array}$ & $0.44 \pm 0.02^{\mathrm{b}}$ & $42.95 \pm 3.13^{\mathrm{b}}$ & $0.145 \pm 0.04^{b}$ \\
\hline $\begin{array}{l}\text { Vit E }\left(100 \mathrm{mg} \mathrm{kg}^{-1}\right) \\
\text { Group VI }\end{array}$ & $0.46 \pm 0.06^{\mathrm{b}}$ & $44.23 \pm 2.51^{\mathrm{b}}$ & $0.166 \pm 0.04^{b}$ \\
\hline $\begin{array}{l}\text { NSE + Vit E } \\
\text { Group VII }\end{array}$ & $0.68 \pm 0.04^{\mathrm{c}}$ & $38.66 \pm 1.31^{\mathrm{c}}$ & $0.177 \pm 0.05^{\mathrm{c}}$ \\
\hline $\mathrm{NSO}+\mathrm{Vit} \mathrm{E}$ & $0.70 \pm 0.01^{\mathrm{c}}$ & $35.30 \pm 1.22^{\mathrm{c}}$ & $0.180 \pm 0.07^{\mathrm{c}}$ \\
\hline
\end{tabular}

Mean \pm SD values in each raw with different superscripts $(a, b, c, d)$ are significant when compared to the control groups at $p<0.05$. $\mathrm{n}=7$ rats/group

Recorded results in Table 5, indicated that oxidative stress induced by potassium bromate significantly $(\mathrm{p}<0.05)$ decreased the activities of Glutathione Peroxidase (GPx), Superoxide Dismutase (SOD) and Catalase (CAT) antioxidant enzymes in liver tissues of rats as compared to the negative control group. Oral administration of NSE or NSE alone and in combination with vitamin $\mathrm{E}$ to rats with oxidative stress significantly $(\mathrm{p}<0.05)$ increased the activities of GPx, SOD and CAT when compared to the control positive group.

\section{DISCUSSION}

The present study was performed to investigate the effect of oral administration of Nigella Sativa Extract
(NSE), its Oil (NSO) alone and in combination with Vitamin E (Vit E) on oxidative stress induced by Potassium Bromate $\left(\mathrm{KBrO}_{3}\right)$ in male rats. The results showed that oxidative stress induced by $\mathrm{KBrO}_{3}$ in rats caused significant decreases in body weight gain and feed efficiency, increases in liver lipid peroxidation and elevation in serum and liver biochemical markers of oxidative stress. These findings were partially similar to those obtained by Abd El-Ghany et al. (2011) who reported that serum bilirubin, AST and ALT enzymes, total cholesterol triglycerides was greatly increased, while the total proteins were significantly decreased in bromobenzene-treated rats when compared to the untreated control group. These findings indicated to injury, impaired function and damage of liver cells 
because of oral ingestion of bromobenzene. The authors also reported a decline in renal mitochondrial function following subchronic and chronic exposure to potassium bromate based on the oxidative stress action of bromate. The bromate toxicity in male rat kidney included changes in energy consumption and utilization in renal cells that involved up-regulation of glycolytic processes, possibly resulting from altered mitochondrial function. Oral ingestion of bromobenzene induced hepatotoxicity that evident from a significant elevation of activities of AST and ALT in male rats with bromobenzene- induced hepatotoxicity (El-Sharaky et al., 2009).

Lipid peroxidation is a complex process that damages the cell structure and function. Peroxidation of cell membrane lipids initiates a loss of membrane integrity; membrane bound enzyme activity and cell lyses. Oxidative damage in tissues can be limited by the defense system of the host. These defenses appear to be inducible by nutrient and non nutrient antioxidants. Low levels of tissue antioxidant enzymes are likely to result in a tissue damage caused by lipid peroxides or protein carbonyls (Pryor and Squadrito, 1995). The increased lipid peroxidation due to oxidative stress induced by potassium bromate in this study was similar to that previously reported by Khan and Sultana (2004) and Abd El-Ghany et al. (2011).

Results of the present study showed that oral administration of Nigella Sativa Extract (NSE) and its Oil (NSO) alone and in combination on Vitamin E (Vit E) to rats with oxidative stress induce by Potassium Bromate $\left(\mathrm{KBrO}_{3}\right)$ improved hepatorenal function, reduced lipid peroxidation and produced good antioxidant activity.

Many medicinal plants were found to possess bioactive constituents which produce high antioxidant activity and prevent peroxidation of lipids. The hepatoprotective action of NSE and NSO reported in the present study was similar to that obtained by Burits and Bucar (2000). The hypocholesterolemic effect of NSE and NSO was in accordance with that reported by Al-Naqeep et al. (2011). The nephroprotective activity of NSO was similar to that reported by Saleem et al. (2012). The antioxidant effect of NSE and NSO reported herein, agreed with that previously reported by Houghton et al. (1995) and Ragheb et al. (2009). The antioxidant effect of NSE and NSO could be attributed to presence of bioactive compound thymoquinone in the oil of Nigella sativa seeds. Thymoquinone was previously reported to possess high antioxidant activity by Houghton et al. (1995). The present results also showed that the effects of NSE and NSO were amplified by their combination with vitamin E.
It well known that vitamin $\mathrm{E}$ regulates oxidation processes in the body and acts as a powerful antioxidant. Previous studies showed that intake of vitamin E can ameliorate the damaging effects of Reactive Oxygen Species (ROS) and other free radicals due to its free radical scavenging activity (Sanoka et al., 1997; Shalaby et al., 2004). Moreover, supplementation of diet with vitamin $\mathrm{E}$ protected sperm DNA from oxidative stress of free radicals (Jedlinska et al., 2006) in rats and increased the activity of antioxidant enzymes involved in the removal of ROS generated by cell metabolism (Caetano et al., 2013). In addition to Adikwu and Nelson (2013) reported that vitamin $\mathrm{E}$ exhibited hepatoprotective effect and decreased oxidative stress in the liver manifested through decrease in microsomal lipid peroxidation. It normalized levels of alanine aminotransferase, aspartate aminotransferase, alkaline phosphatase, serum bilirubin, glutathione superoxide dimutase, lactose dehydrogenase, malondialdehyde and improved histopathological changes in the liver induced by chemical agents.

The results of the current study showed that antioxidant activity of Nigella sativa extract and its oil was potentiated by their combination with vitamin $\mathrm{E}$ in rats.

\section{CONCLUSION}

In conclusion, the results suggest that oral administration of Nigella sativa seeds extract and oil in combination with vitamin $\mathrm{E}$ to rats with oxidative stress improves hepatorenal function, reduces hypercholesterolemia and lipid peroxidation and produces high antioxidant activity. Therefore, intake of Nigella sativa seeds or oil in combination with vitamin E may be beneficial for reducing the oxidative stress in patients who suffer from oxidative stress.

\section{REFERENCES}

Abd El-Ghany, M., A. Ramadan and S. Hassanan, 2011. Antioxidant activity of some agro-industrial peels on liver and kidney of rats exposed to oxidative stress. World J. Dairy Food Sci., 6:105-114.

Adikwu, E. and B. Nelson, 2013. Hepatoprotective effect of vitamin E. Am. J. Pharmacol. Toxicol., 7: 154163. DOI: 10.3844 /ajptsp.2012.154.163

Al-Naqeep, G., A.S. Al-Zubairi, M. Ismail, Z.H. Amom and N.M. Esa, 2011. Antiatherogenic potential of Nigella sativa seeds and oil in diet-induced hypercholesterolemia in rabbits. Evid. Based Complement Alternat Med. DOI: 10.1093/ecam/neq071 
Beckman, J.S. and W.H. Koppenol, 1996. Nitric oxide, superoxide and peroxynitrite: The good, the bad and ugly. Am. J. Physiol., 271: 14241437. PMID: 8944624

Bergmeyer, H.U., P. Schreiber and A.W. Wahlefeld, 1978. Optimization of methods for aspartate aminotransferase and alanine aminotransferase. Clin. Chem., 24: 58-73. PMID: 22409

Bulaj, G., T. Kortemme and D. Goldenberg, 1998. Ionization-reactivity relationship for cystine thiols in polypeptides. Biochem., 37: 8965-8972. DOI: 10.1021/bi973101r

Burits, M. and F. Bucar, 2000. Antioxidant activity of Nigella sativa essential oil. Phytother. Res., 14: 323$328 . \quad$ DOI: 10.1002/10991573(200008)14:5<323::AID-PTR621>3.0.CO;2-Q

Caetano, A.C., L.F. da-Veiga, F.R. Capaldi, S.M. deAlencar and R.M. Bezerra, 2013. The antioxidant response of the liver of male swiss mice raised on a AIN 93 or commercial diet. BMC Physiol., 13: 3-9. DOI: 10.1186/1472-6793-13-3

El-Sharaky, A.S., A.A. Newairy, M.A. Kamel and S.M. Eweda, 2009. Protective effect of ginger extract against bromobenzene-induced hepatotoxicity in male rats. Food Chem. Toxicol., 47: 1584-1590. DOI: $10.1016 /$ j.fct.2009.04.005

Erukainure, O.L., O.V. Oke, F.O. Owolabi, F.O. Kayode, E.E. Umanhonlen and M. Aliyu, 2012. Chemical properties of Monodora myristica and its protective potentials against free radicals in vitro. Oxid. Antioxid. Med. Sci., 1: 127-132. DOI: 10.5455/oams.080712.or.009

Fossati, P., L. Prencipe and G. Berti, 1980. Use of 3, 5 dichloro-2-hydroxyl benzene sulfonic acid/4amylphenazone chromogenic system in direct enzymatic assay of uric acid in serum and urine. Clin. Chem., 26: 227-231.

Halliwell, B. and J. Gutteridge, 1999. Free Radicals in Biology and Medicine. 3rd Edn., Oxford University Press, Oxford.

Haq, A., P.I. Lobo, M. Al-Tufail, N.R. Rama and S.T. Al-Sedairy, 1999. Immunomodulatory effect of Nigella sativa proteins fractionated by ion exchange chromatography. Int. J. Immunopharmacol. 21: 283295. DOI: 10.1016/S0192-0561(99)00010-7

Houghton, P.J., R. Zarka, B. Las Heras and J.R. Hoult, 1995. Fixed oil of Nigella sativa and derived thymoquinone inhibit eicosanoid generation in leukocytes and membrane lipid peroxidation. Planta Med., 61: 33-36. DOI: 10.1055/s-2006-957994
Husdan, H. and A. Rapoport, 1968. Estimation of creatinine by the jaffe reaction a comparison of three methods. Clin. Chem., 14: 222-238.

Jacob, N.J. and P.J. Van-Denmark, 1960. A chemical method for the determination of triglycerides. Arch. Biochem. Biophys., 88: 250-255.

Jedlinska, M., G. Bomba, K. Jakubowski, T. Rotkiewicz and B. Jana et al., 2006. Impact of oxidative stress and supplementation with vitamins $\mathrm{E}$ and $\mathrm{C}$ on testes morphology in rats. J. Reprod., 52: 203-209. DOI: $10.1262 /$ jrd.17028

Khan, N. and S. Sultana, 2004. Abrogation of potassium bromate-induced renal oxidative stress and subsequent cell proliferation response by soy isoflavones in Wistar rats. Toxicology, 201: 173184. DOI: 10.1016/j.tox.2004.04.012

Krajcovicova-Kudlackova, M., M. Valachovicova, C. Mislanova and J. Pribiojova, 2012. Antioxidative vitamins and oxidative lipid and DNA damage in relation to nutrition. Oxid. Antioxid. Med. Sci., 1: 147-151. DOI: 10.5455/oams.130812.or.011

Kurokawa, Y., A. Maekawa, M. Takahashi and Y. Hayashi, 1990. Toxicity and carcinogenicity of potassium bromate, a new renal carcinogen. Environ. Health Perspect., 87: 309-335. DOI: 10.1289/ehp.9087309

Meral, I., Z. Yener, T. Kahraman and N. Mert, 2001. Effect of Nigella sativa on glucose concentration, lipid peroxidation, antioxidant defense system and liver damage in experimentally-induced diabetic rabbits. J. Vet. Med., 48: 593-599. DOI: 10.1046/j.1439-0442.2001.00393.x

Ohkawa, H., N. Ohahi and K. Jadi, 1979. Assay for lipid peroxides in animal tissues by thiobarbituric acid reaction. Anal. Biochem., 95: 351-358. DOI: 10.1016/0003-2697(79)90738-3

Paglia, D.F. and W.N. Valentaine, 1979. Studies on glutathione and glutathione characterization of erythrocytes glutathione peroxidase. J. Lab. Clin. Med., 70: 158-169.

Patton, C.J. and S.R. Crouch, 1977. Enzymatic colorimetric method for determination of urea in serum. Anal. Chem., 49: 464-465. DOI: 10.1021/ac50011a034

Pryor, W.A. and G.L. Squadrito, 1995. The chemistry of peroxynitrite: A product from the reaction of nitric oxide with superoxide. Am. J. Physiol., 268: 699-722. PMID: 7762673 
Ragheb, A., A. Attia, W.S. Eldin, F. Elbarbary and S. Gazarin et al., 2009. The protective effect of thymoquinone, an anti-oxidant and anti-inflammatory agent, against renal injury: A review. Saudi J. kidney Dis. Transpl., 20: 741-752. PMID: 19736468

Randhawa, M.A. and M.S. Alghamdi, 2011. Anticancer activity of Nigella sativa (black seed). A review. Am. J. Chin. Med., 39: 1075-1091. DOI: 10.1142/S0192415X1100941X

Ratliff, C.R. and F. Hall, 1973. A new method for direct colorimetric determination on serum cholesterol. Cited in Laboratory Manual of Clinical Biochemistry, Scoot and White Memorial Hospital publication, Texas, USA.

Reeves, P.G., F.H. Nielson and G.C. Fahmy, 1993. Reports of the American institute of nutrition, adhoc willing committee on reformulation of the AIN 93 Rodent diet. J. Nut., 123: 1939-1951.

Reuter, S., S.C. Gupta, M.M. Chaturvedi and B.B. Aggarwal, 2010. Oxidative stress, inflammation and cancer: How they are linked? Free Radic. Biol. Med., 49: 1603-1616. DOI: 10.1016/j.freeradbiomed.2010.09.006

Rice-Evans, C.A., N.J. Miller and G. Paganga, 1996. Structure-antioxidant activity relationships of flavonoids and phenolic acids. Free Radic. Biol. Med., 20: 933-956. DOI: 10.1016/0891-5849(95)02227-9
Saleem, U., B. Ahmad, K. Rehman, S. Mahmood and M. Alam et al., 2012. Nephro-protective effect of vitamin $\mathrm{C}$ and Nigella sativa oil on gentamicin associated nephrotoxicity in rabbits. Pak. J. Phar. Sci., 25: 727-730. PMID: 23009987

Sanoka, D., R. Miesel, R. Jedzejczak and M. Kurpisz, 1997. Oxidative stress and male fertility. J. Androl, 12: 2434-2436.

Shalaby, M.A., H.Y. El Zorba and M.K. Gehan, 2004. Effect of alpha-tocopherol and simvastatin on male fertility in hypercholesterolemic rats. Pharmacol. Res., 50: 137-142. DOI: 10.1016/j.phrs.2003.10.013

Sinha, K.A., 1972. Colorimetric assay of catalase enzyme. Anal. Biochem., 47: 328-330. DOI: 10.1016/0003-2697(72)90132-7

Spitz, D.R. and L.W. Oberley, 1989. An assay for superoxide dismutase activity in mammalian tissue homogenates. Anal. Biochem., 179: 8-18. DOI: 10.1016/0003-2697(89)90192-9

Worthen, D.R., O.A. Ghosheh and P.A. Crooks, 1998. The in vitro anti-tumor activity of some crude and purified components of blackseed, Nigella sativa L. Anticancer Res., 18: 1527-1532. PMID: 9673365 